\title{
ECOWAS AND THE MAINTENANCE OF INTERNATIONAL PEACE AND SECURITY: PROTECTING THE RIGHT TO DEMOCRATIC GOVERNANCE
}

\author{
Elkanah Oluwapelumi Babatunde*
}

\begin{abstract}
The United Nations (UN) Charter remains the primary instrument for the international regulation of the use of force. However, there are emerging trends in practice, especially by regional organizations, which may be leading to the establishment of a new customary international law rule on pro-democratic intervention. Thus, it is necessary to examine the legality and compatibility of these practices with the UN Charter and other international and regional instruments. It is also important to investigate opinio juris in order to establish whether the international community interprets these practices as a breach of existing international law or indeed as creating new law. This article analyses the permissibility of pro-democratic intervention in light of article 2(4) of the UN Charter, the principle of non-intervention, and other rules guiding the use of force in international law, with a focus on the recent ECOWAS intervention in the Gambia and its consistency with the general body of international law. The article concludes that, albeit illegal, the ECOWAS intervention is legitimate and morally excusable following Reisman's morally-based approach to humanitarian intervention.
\end{abstract}

\section{A. INTRODUCTION}

The United Nations (UN) Charter came into force at the end of the Second World War in 1945. ${ }^{1}$ It affirms the commitment of the nations of the world to international peace and security. ${ }^{2}$ In furtherance of this objective, article 2(4) of the UN Charter expressly bans the use of force in all its forms by states against each other. However, the Charter provides for certain exceptions to this provision: the right to individual and collective self-defence ${ }^{3}$ and the exercise of Chapter VII powers by the UN Security Council. ${ }^{4}$

In a series of events between the Economic Community of West African States ('ECOWAS') and the Republic of Gambia ('Gambia'), ECOWAS intervened in Gambia both politically and militarily. This intervention was in clear breach of article 2(4) of the UN Charter and has called into question a number of international law principles regulating the use of force.

In this article, I address the ECOWAS intervention in line with the general body of international law on the use of force. This article analyses the actions of ECOWAS as a regional organisation under the UN Charter as opposed to the actions of individual member

\footnotetext{
*PhD Candidate, University of Cape Town. Special thanks to Dr Cathy Powell, Lorraine Aboagye and the UCL editorial team for comments on the initial drafts of this paper.

${ }^{1}$ Charter of the United Nations (adopted 26 June 1945, entered into force 24 October 1945) 1 UNTS XVI (UNC).

2 ibid art 1.

3 ibid art 51 .

4 ibid art 42.
} 
states. Although ECOWAS is not a party to the UN Charter, it is nevertheless bound by some of the rules contained therein, including the prohibition of the use of force which has become part of customary international law. The obligations of ECOWAS under the Charter are therefore to be understood in their customary international law form. ${ }^{5}$ The article opens with a brief background of the facts that led to the ECOWAS intervention in Gambia. In the next section, I analyse article 2(4) of the UN Charter and the prohibition on the use of force. I argue that the intervention contravenes the provisions of the UN Charter. Mindful of the powers of the Security Council to authorise the use of force, I proceed in section D to discuss Security Council Resolution 2337 and whether it constitutes a valid legal authority upon which ECOWAS could have intervened in Gambia. A look at this resolution reveals that it did not in any way authorise the use of force by ECOWAS. I further discuss the retroactive effect of Security Council resolutions and conclude that the Security Council resolution in question does not have any retroactive effect.

In section $\mathrm{E}, \mathrm{I}$ discuss the principle of consent and intervention by invitation in relation to the prohibition on the use of force in international law. I examine the plea of the newly elected president of Gambia, Adama Barrow, at his inaugural speech. In light of the conditions regarding authority to give consent on behalf of a state, and the timing of the ECOWAS intervention, I conclude that the ECOWAS intervention was not supported by valid consent from Gambia.

In the absence of any justification for the intervention in the UN Charter, I briefly examine the right of democratic governance in section F. Democratic governance, simply stated, refers to governance based on the lawful consent of the governed. ${ }^{6}$ This article argues that while there is an emerging right of democratic governance, the legality of pro-democratic intervention to enforce this right is yet to be established in international law. There is a scarceness of state practice to support the existence of customary international law permitting such an intervention. Furthermore, opinio juris remains divided and we are far from reaching a consensus recognising the permissibility of pro-democratic interventions. Thus, the intervention of ECOWAS was a clear derogation from established principles of international law.

In section $G$, I address the ECOWAS intervention in the light of the 'illegal but legitimate' conceptual framework. I adopt the argument of Reisman that given the

\footnotetext{
${ }^{5}$ Military and Paramilitary Activities in and against Nicaragua (Nicaragua v United States of America) (Merits) [1986] ICJ Rep 14, [188]-[192].

${ }^{6}$ Thomas Franck, 'The Emerging Right to Democratic Governance' (1992) 86(1) AJIL 46, 46.
} 
ineffectiveness of the collective security system, states may resort to force due to a compelling moral need to respond to certain crisis and argue that certain uses of nondefensive force may be legitimate even in the absence of a Security Council resolution. There are situations where a timely intervention could prevent an imminent humanitarian catastrophe before it escalates and at very little financial and political cost. The use of force in such cases even though illegal is legitimate and morally excusable. The ECOWAS intervention in Gambia is one of such cases.

\section{B. BACKGROUND}

ECOWAS deployed troops against Gambia in January 2017 in response to the democratic crisis that had begun to erupt in the country after the 2016 presidential elections. Priorly, Yahya Jammeh, who gained power in a bloodless coup in 1994, had ruled Gambia and had remained in power until January 2017 winning all presidential elections from then until 2011. On 1 December 2016, Jammeh lost the presidential elections to Adama Barrow, the leader of the Coalition Party in what was widely agreed to be a free and fair election. ${ }^{7}$ In a twist of events, Jammeh, who had earlier accepted the results of the election, subsequently rejected the results and accused the electoral officers of falsifying the election results. ${ }^{8}$ Jammeh filed an action in the Supreme Court of Gambia challenging the election results. Nevertheless, the President-elect, Adama Barrow was sworn in as President of Gambia on 19 January 2017 at the Gambian embassy in Senegal. ${ }^{9}$ Upon taking the oath of office, Barrow made a request to ECOWAS, the African Union ('AU') and the UN Security Council to support the people of Gambia in enforcing and installing the democratically elected government. ${ }^{10}$ ECOWAS troops entered into Gambia immediately after the inauguration of Adama Barrow as President. Yahya Jammeh stepped down from office on 21 January 2017.

It may seem on the face of it that the deployment of forces against Gambia contravenes article 2(4) of the UN Charter. However, it may be argued that this intervention

\footnotetext{
${ }^{7}$ Dennis Foretia, 'Gambia's elections give hope for Africa's democracies' The Washington Post (Washington DC, 8 December 2016) <www.washingtonpost.com/news/global-opinions/wp/2016/12/08/gambias-electionsgive-hope-for-africas-democracies/?utm_term=.a1a183b69304> accessed 2 July 2017.

${ }^{8}$ Ricci Shryock, 'Gambian President Shows No Sign of Leaving Office after Election Defeat', Voice of America (Washington DC, 5 January 2017) <www.voanews.com/a/gambia-president-election-defeat/3664236.html> accessed 2 July 2017.

9 'Al Jazeera, 'Adama Barrow sworn in as Gambia's president in Senegal' Al-Jazeera (Doha, 19 January 2017) $<$ www.aljazeera.com/news/2017/01/gambia-president-adama-barrow-takes-oath-senegal170119170745954.html?> accessed 4 July 2017.

${ }^{10}$ Ruth Maclean, 'Troops enter the Gambia after Adama Barrow is inaugurated in Senegal' The Guardian (London, 19 January 2017) <www.theguardian.com/world/2017/jan/19/new-gambian-leader-adama-barrowsworn-in-at-ceremony-in-senegal> accessed 18 June 2017.
} 
is permissible on a number of grounds, including the plea made by Adama Barrow at his inauguration. It is however necessary to take a closer look at the facts surrounding the deployment in line with the provisions of the UN Charter and customary international law in order to assert whether it conforms with established international law standards. Does the request by Adama Barrow as part of an inaugural speech constitute consent to use force? Was Barrow the right authority at that time to give consent for force to be used on Gambian territory? Did Resolution 2337 of the Security Council have retroactive effect which legitimizes the intervention? Or has pro-democratic intervention become established as a principle of customary international law? This article seeks to address these questions by looking at the UN Charter and state practice since 1945.

\section{THE UN CHARTER AND THE USE OF FORCE}

The UN Charter came into force in 1945 upon its ratification by the five permanent members of the Security Council. ${ }^{11}$ The Charter culminated an age-long attempt at the regulation of the use of force in international relations. ${ }^{12}$ Article 2(4) of the UN Charter provides that '[a]11 Members shall refrain in their international relations from the threat or use of force against the territorial integrity or political independence of any state, or in any other manner inconsistent with the Purposes of the United Nations.'

The UN Charter prohibits the unilateral use of force by states and self-proclaimed coalition of states. ${ }^{13}$ It pre-empts that states engage in armed conflict without acknowledging the existence of war by providing for a general prohibition against the use of force. ${ }^{14}$ The UN Charter thus revolutionises pre-Charter law on the use of force by going beyond war to prohibit all uses of force even where a state of war has not been declared. It is believed that international peace and security is best maintained when the use of force by states is kept to the barest minimum and the political independence and territorial integrity of a state is respected and not interfered with. ${ }^{15}$

In Military and Paramilitary Activities in and against Nicaragua (Nicaragua v United States of America), ${ }^{16}$ the International Court of Justice ('ICJ') noted that prohibited

\footnotetext{
${ }^{11} \mathrm{UNC}$, art 110(3).

${ }^{12}$ Randall Lesaffer, 'Too Much History: From War as Sanction to the Sanctioning of War' in Marc Weller (ed), The Oxford Handbook of the Use of Force in International Law (OUP 2015) 35.

${ }^{13}$ Robert Kolb and Richard Hyde, An Introduction to the International Law of Armed Conflicts (Hart Publishing 2008) 11.

${ }^{14}$ ibid; Olivier Corten, The Law Against War: The Prohibition on the Use of Force in Contemporary International Law (Hart Publishing 2010) 52.

${ }^{15}$ Malcolm Shaw, International Law (6th edn, CUP 2008) 213.

${ }^{16}$ Nicaragua $v$ United States of America (n 5).
} 
intervention only applies to matters over which the state has the sovereign jurisdiction to decide upon. ${ }^{17}$ In other words, the subject matter giving rise to an unlawful intervention must be within the state's exclusive jurisdiction. The Court went further to enumerate some matters, including the choice of political system, as matters within the state's sovereign jurisdiction, stating that any intervention therewith would be unlawful. ${ }^{18}$ Inasmuch as intervention is prohibited in these matters, it is also impermissible to use force vis-à-vis issues for which intervention is prohibited. ${ }^{19}$ The principle of non-intervention forms the overall principle under which the prohibition on the use of force and other forms of coercion such as economic and diplomatic sanctions are based. ${ }^{20}$ It restricts the ability of external bodies to meddle economically, politically or in any way whatsoever in the internal affairs of a state. In other words, the prohibition on the use of force instantiates the principle of nonintervention.

The UN Charter expressly provides for three exceptions to the prohibition of the use of force. First, it exempts the use of force against former enemy states of the Second World War. This exception became obsolete with the admission of the states in question to the United Nations. Secondly, it permits enforcement action by the Security Council in line with its powers enshrined in Chapter VII of the UN Charter. The third exception is the right of states to self-defence enshrined in article 51. The Charter recognises and upholds the right of states to individual and collective self-defence. ${ }^{21}$ Thus, a state will be acting within its rights and within the ambit of the law if it uses force against another state to defend itself against an armed attack. Any measure taken in self-defence must be reported to the UN Security Council. ${ }^{22}$ It is necessary to add that the use of force in the territory of a state is permissible if the state has consented to the deployment of forces. ${ }^{23}$ Beyond these exceptions, every other use of force is centralized into the hands of the Security Council for the maintenance of international peace and security.

\section{Use of force and regional arrangements for peace}

Article 52 of the UN Charter provides that regional arrangements directed towards the maintenance of international peace and security are not precluded by it. The role of regional organizations was acknowledged in the Recommendations of the UN Special Committee on

\footnotetext{
17 ibid [205].

18 ibid.

${ }^{19}$ ibid.

${ }^{20}$ UNGA Res 20/2131 (21 December 1965) UN Doc A/RES/20/2131, Preamble, operative para 2.

${ }^{21} \mathrm{UNC}$, art 51.

22 ibid.

${ }^{23}$ See later discussion in section E.
} 
Peacekeeping Operations. ${ }^{24}$ It is permissible for a regional organisation, such as ECOWAS, to employ whatever measures it deems necessary and appropriate to ensure international peace and security within its region. ${ }^{25}$ However, these measures must not include military action. ${ }^{26}$ Article 53 of the UN Charter does not affect the monopoly of the Security Council over the use of non-defensive force. ${ }^{27}$ A literal interpretation of the provisions of article 53 of the UN Charter reveals that a regional organisation cannot embark on enforcement action until the approval of the UN Security Council for such action has been obtained. ${ }^{28}$ Thus, even though regional arrangements could be made for the maintenance of peace and security, regional organisations are in a subordinate position to the Security Council with respect to the use of force. ${ }^{29}$ In other words, while regional arrangements for international peace and security are permissible under the Charter, the Security Council must authorise such arrangements if military action is involved. ${ }^{30}$

\section{The prohibition against the threat of force}

It is noteworthy that the UN Charter not only prohibits the actual use of force but also the threat of force against a state. ${ }^{31}$ In its advisory opinion on the Legality of the Threat or Use of Nuclear Weapons ${ }^{32}$ the ICJ held that states must refrain from both the use of and the threat of using force. ${ }^{33}$ International law proscribes any form of interference or attempted threat against a state or its political, economic or cultural components. ${ }^{34}$

What constitutes a threat prohibited under Article 2(4)? The ICJ has held that the existence of a threat to use force depends upon various factors. ${ }^{35}$ First, there must be an express intention to use force against a particular state if certain demands are not met. ${ }^{36}$ The threat of force hinges on the promise to use force. ${ }^{37}$ Thus, mere schisms or suspicions between states, without a declared intention to deploy force, do not constitute threat of use of

\footnotetext{
${ }^{24}$ Report of the Secretary-General, 'Implementation of the Recommendations of the Special Committee on Peacekeeping Operations' (2005), UN Doc A/60/64 [29].

${ }^{25} \mathrm{UNC}$, art 52.

${ }^{26}$ ibid art 53.

${ }^{27}$ Ugo Villani, 'The Security Council's Authorization of Enforcement Action by Regional Organizations' in J.A. Frowein and R Wolfrum (eds), MPYUNL (Vol 6, Kluwer 2002) 552.

${ }^{28} \mathrm{UNC}$, art 53; Questions of Interpretation and Application of the 1971 Montreal Convention Arising from the Aerial Incident at Lockerbie (Libya v UK) (Preliminary Objection) [1998] ICJ Rep 9 [44], [38].

${ }^{29}$ Villani (n 27) 537.

${ }^{30} \mathrm{UNC}$, art 53.

${ }^{31}$ ibid art 2(4).

32 [1996] ICJ Rep 226.

33 ibid; Nicaragua $v$ United States (n 5) [227].

${ }^{34}$ Ved Nanda, 'The Validity of United States Intervention in Panama under International Law' (1990) 84(2) AJIL Law 495.

${ }^{35}$ Legality of the Threat or Use of Nuclear Weapons (n 32) [47].

${ }^{36}$ ibid.

${ }^{37}$ Ian Brownlie, International Law and the Use of Force by States (Clarendon Press 1963) 364.
} 
force under article 2(4) of the UN Charter. In addition, the threat of force must be directed towards a specific reaction on the part of the targeted state and accompanied by coercive intent. $^{38}$ There must be a stated course of action which the 'aggressor' wants the threatened state to adopt and hopes to compel the state by the threat of force. The threat and the demand should be clear and directed at an identified state or group of states. ${ }^{39}$ A general statement to use force not directed to a particular or identifiable state or group of states does not amount to a threat of force. Thus, to constitute a threat prohibited under the Charter, there must be intent to use force; certain demands must be made and these must be directed at a particular state or group of states.

The threat of force is illegal in a situation where the actual use of force would also be illegal. ${ }^{40}$ The UN Charter prohibits the threat of force in the same way it prohibits the actual use of force. ${ }^{41}$ Thus, it would only be illegal to threaten force in a situation where its actual use would be illegal. ${ }^{42}$ Threats of force targeted towards a matter within a state's domestic jurisdiction would therefore be in contravention of international law. The ICJ has held that it is impermissible to threaten force against a state in order to compel it to adopt a certain political or economic position. ${ }^{43}$ These are matters within the state's sovereign jurisdiction and coercive external influence in these areas are unjustified. Examples of legal threats of force would include threats in matters for which the Security Council has given approval to use force or threat pursuant to the exercise of the right to self-defence. Otherwise, threats to use force would be impermissible under international law. Threats to use force may include rearmaments, military manoeuvres, the establishment of military bases on the territory of a foreign state, bellicose declarations, concentration of troops along borders, and general mobilisation and propaganda in favour of a war of aggression. ${ }^{44}$

On December 23, 2016, the President of ECOWAS stated that a deadline had been given to Jammeh to step down as president of Gambia, failing which, troops 'already on alert' would intervene to topple the Jammeh-led government. ${ }^{45}$ This unequivocal demand

\footnotetext{
${ }^{38}$ Bruno Simma and others (eds), The Charter of the United Nations: A Commentary, vol 1(OUP 2012) 219.

${ }^{39}$ Francois Dubuisson and Anne Lagerwall, 'Too Much History: From War as Sanction to the Sanctioning of War' in Marc Weller (ed), The Oxford Handbook of the Use of Force in International Law (OUP 2015) 913.

${ }^{40}$ Legality of the Threat or Use of Nuclear Weapons (n 32) [47].

${ }^{41}$ Dubuisson and Lagerwall (n 39) 910.

${ }^{42}$ Legality of the Threat or Use of Nuclear Weapons (n 32).

43 ibid.

${ }^{44}$ Dubuisson and Lagerwall (n 39) 913.

${ }^{45}$ Adam Withnall, 'West African Bloc Threatens to Invade Gambia if Incumbent Jammeh Refuses to Give Up Power' The Independent (London, 23 December 2016) <www.independent.co.uk/news/world/africa/gambiaelection-yahya-jammeh-west-african-bloc-ecowas-senegal-invasion-military-a 7492966.html $>$ accessed 18 June 2017.
} 
made by ECOWAS, supported by a threat that troops were to be deployed against Gambia, amounted to a threat of use of force. There was a clear demand, namely the request that Jammeh steps down as president. Further, the demand regarded a matter within the sovereign jurisdiction of Gambia: ${ }^{46}$ electoral matters are political and fall within a state's sovereign jurisdiction. ${ }^{47}$ There was also coercive intent: ${ }^{48}$ the troops to be used for actualizing the threat were already on alert. ${ }^{49}$ ECOWAS had effectively issued, as of December 23, 2016, a threat to use force against Gambia in violation of international law. This threat materialised on 19 January 2017 with the deployment of 7,000 troops into Gambian territory upon Jammeh's refusal to step down from office. ${ }^{50}$

\section{THE GAMBIAN INTERVENTION AND THE SECURITY COUNCIL}

Given the illegality of the use of force in regional arrangements for peace, Security Council authorisation remains the most compelling argument for intervention in the Gambian case. ${ }^{51}$ The UN Charter empowers the Security Council to determine the existence of a threat to international peace and security and take the necessary measures to restore same. ${ }^{52}$ The Council is further empowered under article 42 of the UN Charter to authorise use of military action where such becomes necessary for the maintenance of international peace and security. Hence, military intervention is permissible if it has prior and explicit approval of the Security Council. ${ }^{53}$ The Charter does not define when there is a threat to or breach of peace or an act of aggression. It leaves the determination on the existence of such circumstances to the discretion of the Security Council. ${ }^{54}$ It must also be stated that there are no settled legal criteria for determining the existence of a threat ${ }^{55}$ - the Security Council is expected to approach each case on its own merits. On those discretionary grounds, when the Council

\footnotetext{
${ }^{46}$ Nicaragua $v$ United States (n 5) [205].

${ }^{47}$ Legality of the Threat or Use of Nuclear Weapons (n 32) [47].

${ }^{48}$ Simma and others (n 38) 219.

${ }^{49}$ Withnall (n 45).

${ }^{50}$ Bryony Jones and others, 'Gambia: Defeated Leader Yahya Jammeh Leaves Country after Election Loss' CNN (Atlanta, 20 January 2017) <edition.cnn.com/2017/01/20/Africa/gambia-janmeh-barrowecowas/index.html> accessed 2 July 2017; Ismail Akwei, 'Senegalese Troops Enter The Gambia as UN Backs ECOWAS Intervention' Africa News (Pointe-Noire, 19 January 2017) $<$ www.africanews.com/2017/01/19/senegalese-troops-enter-the-gambia-as-un-backs-ecowas-intervention//> accessed 18 June 2017.

${ }^{51} \mathrm{UNC}$, arts 39-42.

52 ibid art 39.

${ }^{53}$ Joel Westra, International Law and the Use of Armed Force: The UN Charter and the Major Powers (Routledge 2007) 6.

${ }^{54}$ UNC, art 39; Sydney Bailey, The Procedure of the UN Security Council (2nd edn, Clarendon Press 1988) 295.

55 Jean D'Aspremont, 'The Collective Security System' in Marc Weller (ed), The Oxford Handbook of the Use of Force in International Law (OUP 2015) 147.
} 
finds the crisis in a state to constitute a threat to international peace and security, it bears the authority to authorise the use of military force. ${ }^{56}$

However, the Council may only authorise military intervention if non-military means would be or have already been proven to be inadequate. ${ }^{57}$ Recourse must first be made to pacific means of settling the issues before recourse to armed force is considered. ${ }^{58}$ Beyond the requirement that non-military means should be considered before employing military force, the UN Charter does not contain any more detailed rules guiding the exercise of the Council's Chapter VII powers. ${ }^{59}$ As already stated, the decision remains within the Council's sole discretion. ${ }^{60}$

Notably, the Security Council has tended to intervene in situations which claim to constituting a threat to international peace and security is weak. ${ }^{61}$ In 1994 , the Security Council decided that the overthrow of a democratic government in Haiti constituted a threat to international peace and security and authorised the use of force to restore democracy. ${ }^{62}$ The Security Council also authorised the deployment of forces in support of Cote d'Ivoire to ensure a peaceful democratic process. ${ }^{63}$ Other examples where the Security Council has intervened include the suppression of the internal crisis in Iraq, ${ }^{64}$ the protection of food aid in Somalia, ${ }^{65}$ the suppression of ethnic war in Bosnia, ${ }^{66}$ and the intervention in Libya against the government of Muammar Gaddafi. ${ }^{67}$ Although the Security Council took the cross-border effect of these crises into account in reaching these decisions, they were arguably short of amounting to a threat to peace, breach of peace, or act of aggression constituting a threat to

\footnotetext{
${ }^{56}$ Judy Gallant, 'Humanitarian Intervention and Security Council Resolution 688: A Reappraisal in Light of a Changing World Order' (1992) 7(4) Am U Intl L Rev 881.

${ }^{57} \mathrm{UNC}$, art 42.

${ }^{58}$ Niels Blokker, 'Is the Authorization Authorized? Powers and Practice of the UN Security Council to Authorize the Use of Force by 'Coalitions of the Able and Willing' (2000) 11 EJIL 550.

${ }^{59}$ ibid.

${ }^{60}$ D'Aspremont (n 55) 147.

${ }^{61}$ ibid; Karsten Nowrott and Emily W Schebacker, 'The Use of Force to Restore Democracy: International Legal Implications of the ECOWAS Intervention in Sierra Leone' (1998) 14 Am U Intl L Rev 354.

${ }^{62}$ UNSC Res 940 (31 July 1994) UN Doc S/RES/940.

${ }^{63}$ UNSC Res 1528 (27 February 2004) UN Doc S/RES/1528.

${ }^{64}$ UNSC Res 688 (05 April 1991) UN Doc S/RES/688; UNSC Res 689 (09 April 1991) UN Doc S/RES/689. The intervention referred to here is different from the one pertaining to Kuwait. Some scholars have argued that this resolution did not authorise military intervention. For a full discussion of the Kurdish crisis and exercise of Chapter VII powers, see Schachter, 'United Nations Law in the Gulf Conflict' (1991) 85 AJIL 452; Peter Malanczuk, 'The Kurdish Crisis and Allied Intervention in the Aftermath of the Second Gulf War' (1991) 2 EJIL 128, 128-129; Gallant (n 50) 881.

${ }^{65}$ UNSC Res 733 (23 January 1992) UN Doc S/RES/733.

${ }^{66}$ UNSC Res 941 (23 September 1994) UN Doc S/RES/941.

${ }^{67}$ UNSC Res 1973 (26 February 2011) UN Doc S/RES/1973.
} 
international peace and security. ${ }^{68}$ Once there is a significant level of internal crisis, the Security Council may consider that it has sufficient potential transboundary effect and interfere in such crisis. ${ }^{69}$ A Security Council resolution to intervene in Gambia would not have been unprecedented on these grounds.

Markedly, ECOWAS did not seem to be making any progress in the negotiations with Jammeh. The erstwhile president had maintained his stand to not step down from office even after the winner of the elections had been sworn in at the Gambian embassy in Senegal. He had in addition declared a state of emergency. Jammeh had maintained a position that showed that non-military means were inadequate to address the situation. Barrow on the other hand showed no sign of letting go of his election victory and was sworn into office in Senegal, thus creating a nation with two individuals claiming to be the legitimate head of state. This, coupled with the movement of thousands of Gambians into neighbouring Senegal, shows that there was a real emergency. The imminent character of violence lent reason to the Security Council to intervene and authorise the use of force. An exercise of the Council's powers under Article 42 would thus be justified under the foregoing considerations.

However, the deployment of troops against Gambia was carried out without a Security Council resolution. Although the Security Council later passed Resolution 2337 (2017), this merely endorsed 'the decisions of ECOWAS and the AU to recognize Barrow as President of the Gambia. ${ }^{70}$ The resolution did not go further to authorise military action. In fact, paragraph 9 of the resolution expressly requests all stakeholders to exercise restraint and ensure the peaceful transfer of power. The use of the words 'peaceful transfer of power' puts to rest any doubt with regards to the intention of the Security Council to authorise force against Gambia. The representatives of Russia and Egypt went further to make it clear that the Resolution did not invoke the Chapter VII powers of the Council and that it was instead a call for peaceful resolution of the democratic crisis in Gambia. ${ }^{71}$

\section{Retroactive application of the Security Council resolution 2337}

Even if it were conceded for the sake of discussion that said resolution authorised the use of force, its validity would remain doubtful on the basis that the legality of retroactive authorisations is, at least, contentious. Retroactive endorsements of the use of force by the

\footnotetext{
${ }^{68}$ UNC, art 39; David Wippman, 'Pro-democratic Intervention' in Marc Weller (ed), The Oxford Handbook of the Use of Force in International Law (OUP 2015) 803.

69 ibid.

${ }^{70}$ UNSC Res 2337 (19 January 2017) UN Doc S/RES/2337.

${ }^{71}$ AFP, 'UN unanimously backs Gambia's new president in standoff' Mail Online (London 19 January 2017) $<$ www.dailymail.co.uk/wires/afp/article-4136274/UN-vote-backing-ECOWAS-action-The-Gambia.html> accessed 4 July 2017.
} 
Security Council do exist in the history of military intervention. The first ECOWAS intervention in Liberia had commenced without a Security Council resolution. The Security Council later commended the West African bloc for the restoration of peace in Liberia. ${ }^{72}$ This situation was repeated in 1993 when ECOWAS intervened in Sierra Leone without first obtaining Security Council approval. Again, the ECOWAS Cease-Fire Monitoring Group (ECOMOG) intervention was commended. ${ }^{73}$ The Security Council passed a resolution thereafter, ${ }^{74}$ which formally ratified the ECOMOG intervention and also authorised a UN force, the UN Mission in Liberia (UNAMIL), to assist ECOMOG. ${ }^{75}$ However, the legal effect of these retroactive authorisations remains a grey area ${ }^{76}$ as the international community seems to be more concerned with the success of these interventions rather than their 'technical' requirement. ${ }^{77}$

In Libya $v U K,{ }^{78}$ the ICJ declined to give retroactive effect to a Security Council resolution. ${ }^{79}$ A resolution adopted by the Security Council after the deployment of forces cannot authorise that use of force as the force was used irrespective of the Council's resolution. Considering that the purpose of the UN collective security system is to ensure that the Security Council has effective control over non-defensive use of force, it follows that authorisation must precede the action. ${ }^{80}$ An interpretation of the Charter which gives effect to the retroactive application of resolutions leaves the use of non-defensive force out of the effective control of the Security Council. Adopting an interpretation which requires that authorisation be given priorly ensures that the use of force is kept to the bare minimum and encourages the pacific settlement of disputes. This construction also protects the sovereignty of states and restricts external interference into the internal affairs of a state. ${ }^{81}$ Thus, Resolution 2337 cannot be relied upon as a basis for the legality of the intervention by ECOWAS. This resolution did not authorise the use of military force; rather, it emphasized

\footnotetext{
${ }^{72}$ David Wippman, 'Enforcing the Peace: ECOWAS and the Liberian Civil War' in Lori Damrosch (ed), Enforcing Restraint: Collective Intervention in Internal Conflicts (Council on Foreign Relations Press 1993) 183.

${ }^{73}$ UNSC Res 856 (10 August 1993) S/RES/856 [6]; UNSC Res 866 (22 September 1993) S/RES/866.

${ }^{74}$ UNSC Res 1270 (22 October 199)9) S/RES/1270.

${ }^{75}$ Thomas Franck, 'Interpretation and Change in the Law of Humanitarian Intervention' in JL Holzgrefe and Robert Keohane (eds), Humanitarian Intervention: Ethical, Legal and Political Dilemmas (CUP 2003) 222.

${ }^{76}$ Wippman, 'Pro-democratic Intervention' (n 68) 805.

${ }^{77}$ ibid.

${ }^{78}$ Questions of Interpretation and Application of the 1971 Montreal Convention Arising from the Aerial Incident at Lockerbie (Libya $v$ UK) (Preliminary Objection) [1998] ICJ Rep 9.

79 ibid [44].

${ }^{80}$ Villani (n 27) 551; Christian Walter, 'Security Council Control over Regional Action' in Jochen Frowein and Rudiger Wolfrum (eds), MPYUNL, vol 1 (Kluwer 1997) 177.

${ }^{81}$ Jane Stromseth, 'Rethinking Humanitarian Intervention: The Case for Incremental Change' in JL Holzgrefe and Keohane (eds), Humanitarian Intervention: Ethical, Moral and Political Dilemmas (CUP 2003) 242.
} 
the employment of pacific means for the settlement of the crisis. Also, a strict interpretation of the Charter leads to the conclusion that the authorisation for an intervention must be given prior to the deployment of forces, rendering retroactive authorisations as illegal under that legal framework.

\section{E. CONSENT TO USE FORCE}

There is consensus that the prohibition on the use of force is a peremptory norm of international law from which states are not permitted to derogate. ${ }^{82}$ In Nicaragua, the ICJ upheld this position and stated that the prohibition against the use of force is "not only a principle of customary international law but also a fundamental or cardinal principle of such law. ${ }^{83}$ However, the prohibition provided for in article 2(4) of the UN Charter places a state under the 'dictatorial interference' of other states. ${ }^{84}$ ECOWAS' presence in Gambia would not have been dictatorial if the consent of the right state authority had been obtained, which in turn entails that the peremptory rule would have not been breached. There have been situations in the past where states have relied on consent as the basis for the use of force on foreign territory and these arguments have been generally accepted by the international community. ${ }^{85}$ France and the United Kingdom (UK), for example, have relied on consent as the justification for intervention in their former colonies and states generally agreed with this interpretation of the law. ${ }^{86}$

Accordingly, a state's consent to the foreign use of force in its territory is generally acknowledged to be permissible. ${ }^{87}$ Thus, such force would be consistent with article 2(4) of the Charter, insofar as it stays within the ambit of the given consent. In DRC v Uganda, ${ }^{88}$ the ICJ held that the use of force by Uganda in DRC territory to fight a common enemy was

\footnotetext{
${ }^{82}$ ILC, 'Report of the International Law Commission on the Work of its 18th Session (4 May - 19 July 1966) UN Doc A/CN.4/191, Supplement No. 9 (A/6309/Rev.1) ch C.V, 248; James Crawford, The Creation of States in International Law (2nd edn, OUP 2006) 146; Yoram Dinstein, War, Aggression and Self-Defence (4th edn, CUP 2005) 99-104; Lauri Hannikainen, Peremptory Norms in International Law: Historical Development, Criteria, Present Status (Finnish Lawyers' Pub Co 1988) 356; Alexander Orakhelashivili, Peremptory Norms in International Law (OUP 2006) 50; Nicholas Wheeler, Saving Strangers: Humanitarian Intervention in International Society (OUP 2000) 44-45; Jochen Frowein, 'Jus Cogens', in Riidiger Wolfrum (ed), MPEPIL (OUP 2009); Oscar Schachter, 'In Defense of International Rules on the Use of Force' (1986) 53 U Chi L Rev 113, 129; Louis Henkin, 'The Use of Force: Law and U.S. Policy' in Louis Henkin et al (eds), Right and Might: International Law and the Use of Force (Council on Foreign Relations 1991) 37-38; James Green, 'Questioning the Peremptory Status of the Prohibition of the Use of Force' (2001) 32(2) MJIL 221.

${ }^{83}$ Nicaragua (n 16) [199]-[200].

${ }^{84}$ Wippman, 'Pro-Democratic Intervention by Invitation' (n 98) 295.

85 ibid.

86 ibid.

${ }^{87}$ Armed Activities on the Territory of the Congo (Democratic Republic of the Congo v Uganda) [2005] ICJ Rep 168 [46]; Wippman, 'Pro-democratic Intervention' (n 68) 805.

${ }^{88}$ Democratic Republic of the Congo v Uganda (n 87).
} 
permissible if the consent of DRC was established. ${ }^{89}$ Thus, state consent is recognized under international law as a justification for the use of force within the territory of a sovereign state. $^{90}$

During his inaugural speech, Adama Barrow made a special appeal to ECOWAS, the $\mathrm{AU}$ and the UN to support the people of Gambia in enforcing their will, restoring sovereignty and constitutional legitimacy. ${ }^{91}$ It has been asserted that this statement by Barrow constitutes an invitation by Gambia and dispels the need for a Security Council approval. ${ }^{92}$ In order to substantiate this position, two questions must be addressed. First, does the statement, made as part of an inaugural speech, constitute consent? Secondly, who is the right person to consent to the deployment of foreign troops on behalf of the state, Adama Barrow or the erstwhile president, Yahya Jammeh?

\section{What is consent?}

There is no generally accepted definition of what constitutes consent and how such consent is to be expressed. However, it is clear that consent can be explicit or implicit as long as it is clearly established. ${ }^{93}$ The ICJ held in DRC $v$ Uganda that for a statement to constitute valid consent, it must be clear and express. ${ }^{94}$ Barrow's statement asking for support from the international community did not contain an express plea for military intervention. However, his use of the word 'enforce' seems to have the implication that he was requesting various forms of support including military if necessary. In DRC $v$ Uganda, the ICJ held that a statement to 'cooperate in order to insure security and peace along the common border' constituted consent to use force even though the words 'force' or 'military' were not used. ${ }^{95}$ There also seems to be an understanding among stakeholders in the events leading to the inauguration of Barrow as President that the use of armed forces may become necessary, especially after the state of emergency was declared by Yahya Jammeh. It is thus reasonable to state that Adama Barrow had military force in contemplation when seeking for international support during his inauguration.

\section{Who is the right authority to consent?}

\footnotetext{
${ }^{89}$ ibid [46].

${ }^{90}$ Malanczuk (n 64) 123-124.

${ }^{91}$ Maclean (n 10).

${ }^{92}$ Michelle Nichols, 'Update 1: U.N. Backs West African Efforts to Install New Gambia President' Reuters Africa (London, 19 January 2017) <af.reuters.com/article/gambiaNews/idAFL1N1F91AL?sp=true $\geq$ accessed 19 June 2017.

${ }^{93}$ ILC, 'Eighth Report on State Responsibility by Special Rapporteur Robert Ago' (29 February, 10 and 19 June 1980) UN Doc A/CN.4/318/ (Ago Report); Eliav Lieblich, 'Intervention and Consent: Consensual Forcible Interventions in Internal Armed Conflicts as International Agreements' (2011) 29 B U Intl L J 349.

${ }^{94}$ DRC v Uganda (n 87) [42]-[54], [92]-[105].

95 ibid [46].
} 
The next question is whether Adama Barrow is the right authority to give consent on behalf of Gambia. Generally, international law recognizes the government in effective control of the whole or substantial part of the territory as the right authority to give or withhold consent to intervene in a state. ${ }^{96}$ A government must be effective to be recognized and this entails control of a substantial part of the territory, habitual obedience of the population and the likelihood of remaining in power. ${ }^{97}$ Intervention without the consent of a government in effective control is deemed illegal even if such intervention is to replace a dictator with a democratically elected government. ${ }^{98}$ However, state practice and opinio juris on recognition of governments remain inconsistent and it is difficult to draw a general conclusion on what precisely is needed for a government to be recognized. ${ }^{99}$

There have been instances where states and international organizations have intervened based on consent given by an ousted but democratically elected government. ${ }^{100}$ However, the governments in question were ousted governments that had previously been in power. Thus, they had met these criteria at some point, the only issue being that they no longer met them at the time of intervention. Barrow on the other hand had never been in power. He had never been in control of any part of the Gambian territory, nor had any duty of allegiance or obedience towards him arisen on the part of the Gambian populace. There is no precedent under international law that can be relied on for justifying the argument that his government, which practically did not exist at the time, could be recognized. In light of this, Adama Barrow was not the rightful authority to consent to the use of force in Gambian territory and his plea for support cannot be regarded as due consent. ${ }^{101}$

Even if it is conceded that Barrow was the lawful authority to give such consent, the deployment of troops by ECOWAS would nevertheless remain illegal as ECOWAS never relied on Adama Barrow's request as the ground for its deployment of troops. The ECOWAS deployment of force was independent of Gambian consent. ECOWAS had agreed in its $50^{\text {th }}$ Ordinary Session on 17 December 2016 that it would take 'all necessary measures to strictly

\footnotetext{
${ }^{96}$ Wippman, 'Pro-democratic Intervention' (n 68) 805.

${ }^{97}$ Catherine Drummond, 'Rival Governments and the Authority to Represent the State: Was the Use of Force by ECOWAS in the Gambia a Violation of International Law' ILA Reporter (London, 5 February 2017) $<$ ilareporter.org.au/2017/02/rival-governments-and-the-authority-to-represent-the-state-was-the-use-of-forceby-ecowas-in-the-gambia-a-violation-of-international-law-catherine-drummond/> accessed 2 July 2017.

${ }_{98}$ David Wippman, 'Pro-Democratic Intervention by Invitation' in GH Fox and Brad Roth (eds), Democratic Governance and International Law (CUP 2000) 293-295.

${ }^{99}$ Drummond (n 97).

${ }^{100}$ Wippman, 'Pro-democratic Intervention' (n 68) 805. The Haitian and Sierra Leone cases are examples of such cases.

${ }^{101}$ Antenor Hallo de Wolf, 'Rattling Sabers to Save Democracy in the Gambia' (EJIL:Talk!, 1 February 2017) <www.ejiltalk.org/rattling-sabers-to-save-democracy-in-the-gambia/> accessed 11 February 2017.
} 
enforce the 2016 elections' and ensure that Adama Barrow is inaugurated as President of Gambia. ${ }^{102}$ The decision to deploy troops had been taken a month before Barrow's call for support and ECOWAS began to deploy troops at the Gambian border shortly before the inauguration. It is therefore untenable that ECOWAS acted based on state consent. The threat of force and the actual deployment of force into Gambian territory without prior Security Council authorisation constitute a breach of the UN Charter. This illegality would have been cured if the decision to deploy force and the actual deployment of force was on the basis of an invitation by the rightful authority of Gambia.

\section{Prior consent through treaty}

In the alternative, it could be argued that consent was not necessary as consent had been received a priori through regional treaties ${ }^{103}$ such as the Protocol Relating to the Mutual Assistance on Defence and the Protocol Relating to the Mechanism for Conflict Prevention, Management, Resolution, Peace-Keeping and Security. The Protocol Relating to the Mutual Assistance on Defence established a multinational defence force authorised to intervene in armed conflict between member states and in internal armed conflicts supported actively from outside the state. ${ }^{104}$ However, intervention could only occur after the leader of the state involved had forwarded a written request to the appropriate ECOWAS authority. ${ }^{105}$ ECOWAS cannot intervene without such a written request. Article 18 of the Protocol expressly prohibits ECOWAS intervention when the conflict remains purely internal.

The Protocol relating to the Mechanism for Conflict Prevention, Management, Resolution, Peace-Keeping and Security also established a mechanism permitting the use of force within the territory of member states. However, the Protocol provided expressly for the circumstances during which this mechanism was to be utilized. ${ }^{106}$ With respect to democracy, interventions were limited to 'the event of an overthrow or attempted overthrow of a democratically elected government. ${ }^{, 107}$ This implies that this mechanism would only be deployed for a sitting government that was being overthrown and not to establish a democracy that had never been in power. Gambian consent to the Protocol cannot be relied upon as a ground for the intervention. There was no written request as provided for in the

\footnotetext{
${ }^{102}$ Economic Community of West African States (ECOWAS), 'Final Communique 8 of the $50^{\text {th }}$ Ordinary Session of the ECOWAS Authority of Heads of States and Governments' (Abuja, 17 December 2016).

${ }^{103}$ de Wolf (n 101).

${ }^{104}$ ECOWAS, 'Protocol Relating to Mutual Assistance on Defence' (Freetown, 29 May 1981) Protocol A/SP.3/5/81, art 4 .

${ }^{105}$ ibid art 16.

${ }^{106}$ ECOWAS, 'Protocol Relating to the Mechanism for Conflict Prevention, Management, Resolution, PeaceKeeping and Security' (Lomé, 10 December 1999) Protocol A/P.1/12/99 art 25.

107 ibid.
} 
Protocol Relating to the Mutual Assistance on Defence, the crisis remained a purely internal crisis at the time of intervention and the intervention did not regard restoring an overthrown government. Hence, it is clear that Gambia did not consent a priori through treaty.

It is clear from the foregoing that there was no valid consent from Gambia, whether expressed through treaty or by the rightful authority after the facts had emerged, permitting ECOWAS to use force on Gambian territory. It is therefore necessary to examine whether the right to democratic governance is recognised under international law and if so, whether the use of force can be employed to protect this right. The following section will assess whether democratic governance has become a norm of general international law.

\section{F. THE RIGHT TO DEMOCRATIC GOVERNANCE}

Despite the clear illegality of the ECOWAS deployment of force in Gambia, this action has received very little condemnation. Does this imply that the right to democratic governance and the use of force for its enforcement, even without a Security Council resolution, has become fully entrenched under customary international law?

Debates around pro-democratic intervention became popular during the post-Cold War era. These came as offshoots of the arguments by the United States ('US') and the UK on the need to bring 'democracy and freedom' to Iraq and the Middle East. ${ }^{108}$ Several treaties and declarations at the end of the Cold War therefore reinforced the principle of democratic governance and made governmental legitimacy conditional upon the respect of democratic norms and principles. ${ }^{109}$ Regional organizations began to impose the duty to respect and ensure democratic principles as a condition for recognizing new states and for accepting new members. ${ }^{110}$ Organizations such as the Organization for Security and Cooperation in Europe ('OSCE') and the Organization of American States ('OAS') went as far as undertaking to defend and protect the democratic order of its members. ${ }^{111}$ The AU has also played a key role in maintaining democratic governance among its member states. States and various regional organizations have condemned coups that displace elected governments and sometimes place sanctions on such undemocratic regimes. ${ }^{112}$

The effect of this is that there seems to be a growing acceptability of interventions for the sake of upholding democracy in a foreign state. This is especially so on the West African

\footnotetext{
${ }^{108}$ Michael Byers, War Law: Understanding International Law and Armed Conflict (Grove Press 2005$) 85$.

${ }^{109}$ Wippman, 'Pro-democratic Intervention' (n 68) 801.

110 ibid.

${ }^{111}$ Document of the Copenhagen Meeting of the Conference on the Human Dimension of the Conference on Security and Cooperation in Europe (OSCE) (Signed 29 June 1990) (1990) 29 ILM 1305.

112 Wippman, 'Pro-democratic Intervention' (n 68) 799; ECOWAS has been particularly active in this regard.
} 
sub-region where the success of pro-democratic interventions has been frequent. ECOWAS has over the years committed itself to opposing unconstitutional governments through the employment of force. In 1998, ECOWAS helped to reinstate the democratically elected government of Sierra Leone which had been ousted by military officers. Despite the fact that this intervention was without Security Council approval, it was neither condemned by the Security Council or by any state within the international community. Instead, the Security Council lauded ECOWAS on its role in ensuring stability. ${ }^{113}$ The only state that raised concerns as to the legality of this action was Russia which insisted that such actions should only be taken with prior Security Council authorisation. ${ }^{114}$ ECOWAS has also intervened in Cote d'Ivoire and the Central African Republic without prior Security Council approval and these interventions have been met little criticism.

However, opinio juris on the legal effect of this practice is not uniform. In the Liberian crisis, the US maintained that the crisis was an internal one that should be resolved by Liberians. ${ }^{115}$ And even though the UN had passed a resolution sanctioning the RUF junta, ${ }^{116}$ it refused to authorise military intervention. It was this refusal that created the gap which caused ECOWAS to deploy military action. ${ }^{117}$ Similarly in the Sierra Leone case explained above, the intervention was based on the consent of an extant government.

In his arguments in support of pro-democratic interventions, Reisman stated that the prohibition on the use of force provided for in article 2(4) of the UN Charter is predicated on a system of collective security. ${ }^{118}$ Reisman argues that given the ineffectiveness of the collective security system under the UN Charter, the prohibition on unilateral use of force should now be differently construed. ${ }^{119}$ According to Reisman, states should engage in the use of force as a result of compelling moral situations. Further, rather than forbid all forms of use of force, the determination of which uses of force are to be allowed should be made on a case by case basis. ${ }^{120}$ That determination hinges on two criteria, argues Reisman: Firstly, the use of force in question must contribute to or enhance the maintenance of world order. ${ }^{121}$

\footnotetext{
${ }^{113}$ UNSC, Statement by the President of the Security Council [on "The situation in Sierra Leone"] (6 August 1997) S/PRST/1997/42.

${ }^{114}$ UNSC Press Release, 'Security Council Unanimously Approves Sanctions Regime against Sierra Leone' (8 October 1997) SC 6425.

${ }^{115}$ Statement of Hon. Herman J Colen cited in Jeremy Levitt, 'Humanitarian Intervention by Regional Actors in Internal Conflicts: The Cases of ECOWAS in Liberia and Sierra Leone' (1998) 12 TICLJ 346.

${ }^{116}$ UNSC Res 1132 (08 October 1997) S/RES/1132.

${ }^{117}$ Wippman, 'Enforcing the Peace: ECOWAS and the Liberian Civil War' (n 72) 165.

${ }^{118}$ Michael Reisman, 'Coercion and Self-Determination: Construing Article 2(4)' (1984) 78 AJIL 642.

119 ibid.

${ }^{120}$ ibid 643 .

${ }^{121}$ ibid.
} 
Secondly, the action must be politically legitimate in terms of enhancing the rights of people to determine their own political destinies. ${ }^{122}$ According to him, every application of article 2(4) must enhance the right of peoples' self-determination and the analysis of whether use of force is consistent with that provision must always pay due regard for this underlying principle. $^{123}$

Similarly, Franck argues in support of the emerging right to democratic governance. ${ }^{124}$ Franck, relying on events in Russia and Haiti notes that the international community had upheld the notion that democracy validates governance and the legitimacy of governments had come within the purview of international law. ${ }^{125}$ Franck however accepted that this rule was yet to be fully established in international law, but asserted that it was definitely emerging and citizens could now look to the international community for the protection of their democratic entitlement. ${ }^{126} \mathrm{He}$ argued that where there was a violation of such a democratic right or a refusal to permit free and fair elections or to respect the outcome of such elections, there should be consequences ranging from sanctions and blockades to military intervention, where necessary. However, these consequences were to be imposed collectively rather than unilaterally. ${ }^{127}$ Teson, another leading scholar, has suggested that force used for restoring democracy does not engage the prohibition contained in the UN Charter. ${ }^{128}$ Given the purposes of the UN, argues Teson, it would be permissible to use force for deposing a despotic regime. ${ }^{129}$ Generally, these authors rely on a purposive interpretation of the UN Charter and hold that pro-democratic interventions help to further achieve the purpose and objectives of the UN Charter. ${ }^{130}$ They contend that the Charter prohibition was established to protect political independence and territorial integrity of states and an that interventions which do not affect any of these objectives is thus permissible under the that legal framework. ${ }^{131}$

\footnotetext{
122 ibid.

123 ibid.

124 Franck (n 6).

125 ibid 47.

126 ibid 50.

127 ibid 85.

${ }^{128}$ Fernando Teson, Humanitarian Intervention: An Inquiry into Law and Morality (2nd edn, Transnational 1997) 151.

129 ibid.

${ }^{130}$ Nowrott and Schebacker (n 61) 337.

131 Anthony D'Amato, 'The Invasion of Panama Was a Lawful Response to Tyranny' (1990) 84 AJIL 520. A major difference in this strand of argument is that while Reisman argues for unilateral intervention, Franck insists that democratic intervention does not entitle individual states or regional organizations to intervene; such intervention must be carried out collectively through the Security Council.
} 
The right of members of a state to determine their governance and political system is a basic principle recognised under international law. This right includes the freedom of competing groups to disagree and fight or to revolt against their government. ${ }^{132}$ Therefore, armed interference by a foreign (or regional) actor in this political process deprives the people of the right to decide and conclude their political process by themselves. ${ }^{133}$ As stated by the ICJ in its advisory opinion on the Legality of the Use or Threat of Nuclear Weapons, political matters remain within the domestic jurisdiction of a state. The use of force for democratic intervention thus constitutes 'a use of force against the political independence...' of a state and hence, a clear breach of article 2(4). ${ }^{134}$

The establishment of exceptions to the prohibition of use of force beyond the clear wording of the Charter would lead to a 'legion of loopholes' and would expose the Charter to abuse and derogations. ${ }^{135}$ Any loosening of the interpretation of the prohibition against the use of force has the potential to create a situation where the norm gives room for so many exceptions that the rule is a result deprived of any effective application. ${ }^{136}$ Louis Henkins has noted that even humanitarian intervention could become a pretext for aggression. ${ }^{137}$ Although Reisman provides two criteria for the determination of a pro-democratic intervention, these criteria are insufficient to prevent abuse. Who decides that these criteria have been met and upon what legal basis does such an authority make this decision? Moreover, the criteria are highly normative and cannot be measured or assessed in concrete terms. With regards to the maintenance of world order for example, how does one determine the level of intensity which an internal crisis must have for it to affect world order? These criteria therefore become unhelpful in deciding when a state or regional organization may intervene.

International law evolves through state consent whether through treaties or state practice. ${ }^{138}$ The actions of states are restricted by free will expressed through treaties, agreements or 'usages generally accepted as expressing principles of law'. ${ }^{139}$ Changes to the international legal order cannot be assumed where such changes are not established in a

\footnotetext{
${ }^{132}$ Oscar Schachter, 'International Law: The Right of States to Use Armed Force' (1984) 82 Mich L Rev 1641.

133 ibid.

134 ibid.

${ }^{135}$ Yoram Dinstein, War, Aggression and Self-Defense (2nd edn, CUP 1994) 85.

${ }^{136}$ Oscar Schachter, 'Is There a Right to Overthrow an Illegitimate Regime?' in Michel Virally (ed), Le Droit International Au Service de la Paix de la Justice et du Développement (A Pedone 1991) 427.

${ }^{137}$ Louis Henkin, How Nations Behave (2nd edn, Columbia University Press 1979) 145.

138 Anthony Arend, 'International Law and the Pre-emptive Use of Military Force' (2003) 26(2) The Washington Q 91.

${ }^{139}$ The Case of the S.S. "Lotus" (France v Turkey) (Judgment No 9) PCIJ Series A No 10.
} 
treaty or custom. ${ }^{140}$ In this case, there is no treaty law which supports or affirms the legality of pro-democratic intervention. While there seem to be a number of cases where prodemocratic interventions have been carried out, it remains insufficient to reach a positive conclusion regarding the opinio juris element of customary rules as positions are widely divided. ${ }^{141}$ Such interventions remain a violation of the extant law on the use of force. ${ }^{142}$

\section{G. THE LEGITIMACY OF PRO-DEMOCRATIC INTERVENTIONS}

\section{Illegal but legitimate: moral considerations in the assessment of international conducts}

The former Secretary General of the UN, Kofi Annan asked the now popular question: ' ...if humanitarian intervention is, indeed, an unacceptable assault on sovereignty, how should we respond to a Rwanda, to a Srebrenica - to gross and systematic violations of human rights that affect every precept of our common humanity? ${ }^{143}$ Although Kofi Annan spoke about humanitarian intervention, this question could also be applied to the discussions on prodemocratic intervention, especially when one takes into account the violence that often accompanies political crises and how it can quickly lead to the breach of the people's human rights. Should violations of people's political rights be overlooked in favour of the protection of state sovereignty and political independence?

State practice reveals that there is an inclination within the international community to answer this question in the negative. There have been a number of interventions, especially in the West African sub-region, which were largely condoned despite the fact that these interventions were in breach of international law. ${ }^{144}$ There is an acknowledgement that certain circumstances would give room for an unavoidable breach of the law in order to protect the members of a state. Such necessity for action and the danger of failure to act is exemplified in the Rwandan genocide of 1994. The genocide had started as an internal crisis between the Hutus and Tutsis of Rwanda and eventually led to the death of about a million Rwandans. ${ }^{145}$ Even though many have condemned the failure of the international community

\footnotetext{
140 ibid.

${ }^{141}$ Even within the school of thought which allows for pro-democratic intervention, there is no agreement as to whether this should be unilateral or collectively done.

${ }^{142}$ Wippman, 'Pro-democratic Intervention' (n 68) 801.

${ }^{143}$ International Commission on Intervention and State Sovereignty, The Responsibility to Protect (International Development Research Centre 2001) VII.

${ }^{144}$ The interventions in Liberia and Sierra Leone were condoned and later affirmed by the United Nations despite the lack of a prior Security Council resolution in support of the interventions.

${ }^{145}$ Alain Destexhe, 'The Third Genocide' (1994) 97 Foreign Policy 3, 3-4.
} 
to act, ${ }^{146}$ there was indeed no legal duty incumbent on the international community to take military action in Rwanda. ${ }^{147}$ If anything, the international community had stayed within bounds of the legal requirement prohibiting interference in the political independence and territorial integrity of a state. Despite the illegality or otherwise of the conduct, there is consensus that the international community should have acted. A timely intervention would arguably have helped to save the lives that were lost. It therefore becomes imperative that there are situations where intervention, though illegal, would be welcome or better put, legitimate.

Common sense of justice and morality may require that states act outside the strict provisions of the law in order to ensure a just outcome in a given situation. ${ }^{148}$ Thomas Franck explains this with an illustration of two boys whose fathers had a fight. The father of one of the boys consequently instructed his son to 'never to have anything to do' with the other boy. On the next day, this boy saw his friend who could not swim drowning and decided to help him. This was obviously contrary to his father's instruction but his action was definitely justifiable and punishing him for rescuing the boy would be 'morally wrong' ${ }^{149}$ Legitimacy, as used here, refers to moral or philosophical standards of higher status upon which the validity or acceptability of an act or exercise of power is judged. ${ }^{150}$ In other words, an act would be legitimate if it is supported by a higher normative standard. Even if illegal, an act which ensures justice in a given situation would be regarded as legitimate.

The assessment of legitimacy focuses on the desired outcome of a conduct as compared with the result of a refusal to act or to take some other course of action. This framework of analysis looks beyond the law to assess if there are other factors which would compel action in a manner inconsistent with the law, if compliance with the law would lead to situations that are humanly unjustifiable. In reaching the conclusion that NATO intervention in Kosovo was legitimate, the Kosovo Commission reached the conclusion that the intervention was legitimate due to the fact that 'the intervention had the effect of liberating the majority [of the] population of Kosovo.' ${ }^{151}$ The focus was on the impact of the

\footnotetext{
${ }^{146}$ Alain Destexhe, Rwanda and Genocide in the Twentieth Century (Pluto Press 1995); Samantha Power, 'Bystanders to Genocide' The Atlantic (Washington DC, September 2001).

<www.theatlantic.com/magazine/archive/2001/09/bystanders-to-genocide/304571/> accessed 3 July 2017.

${ }^{147}$ The right to humanitarian intervention is yet to be a recognized principle of international law.

148 Thomas Franck, Recourse to Force: State Action against Threats and Armed Attacks (CUP 2002) 177-179.

149 ibid.

${ }^{150}$ Peter Malanczuk, Humanitarian Intervention and the Legitimacy of the Use of Force (Het Spinhuis 1993$) 5$.

${ }^{151}$ The Independent International Commission on Kosovo, The Kosovo Report: Conflict International Response, Lessons Learned (OUP 2000) 5.
} 
intervention on Kosovars. ${ }^{152}$ And it was held as legitimate because it helped to protect the people who would otherwise be subject to further abuse of their rights. ${ }^{153}$ It is therefore necessary to assess the ECOWAS intervention in light of some other principle or set of principles outside the strict interpretation of the law.

\section{Legitimacy of the ECOWAS intervention in Gambia}

The principles underpinning human rights, as well as the principles of justice and morality offer a basis for arguing for the legitimacy of the ECOWAS intervention in Gambia. ECOWAS intervened on behalf of the people who exercised their right to selfdetermination. ${ }^{154}$ Self-determination entails the right of members of a state to freely determine their political status. ${ }^{155}$ Civil and political rights constitute one of the generations of human rights recognized under international law. ${ }^{156}$ This class of rights provides that a person shall be free to participate in the civil and political life of his society without discrimination or repression. ${ }^{157}$ The people of Gambia exercised this right via the polls and chose Adama Barrow as their president. Jammeh on the other hand refused to yield to the mandate of the people and insisted on staying in power. Even though international law recognises the right to self-determination, there is no consensus on the use of force as a means to ensure that right vis-à-vis foreign states, save for events where the Security Council has authorised this in the exercise of its Chapter VII authority. Nevertheless, ECOWAS intervened.

The legitimacy of this intervention can be justified upon the philosophical underpinnings of the legal principles and rules dealing with human rights. These principles are founded on basic morality and justice. ${ }^{158}$ This morality is an intrinsic attribute of mankind, and possesses an inherent significance which human beings, irrespective of where they are, cannot alter. ${ }^{159}$ Gross human rights violations in any part of the world shock the conscience of all mankind and it is the duty of each state to protect the rights of everyone

\footnotetext{
152 ibid.

153 ibid.

${ }^{154}$ UNC; International Covenant on Civil and Political Rights (adopted 16 December 1966, entered into force 23 March 1976) 999 UNTS 171 (ICCPR); International Covenant on Economic, Social and Cultural Rights' (adopted 16 December 1966, entered into force 3 January 1976) 993 UNTS 3 (ICESCR). Gambia is party to all three instruments.

${ }^{155}$ UNC; ICCPR.

156 ibid.

${ }^{157}$ ICCPR arts $1,25$.

158 Teson (n 128) 14.

159 JL Holzgrefe 'The Humanitarian Intervention Debate' in JL Holzgrefe and Robert Keohane (eds), Humanitarian Intervention: Ethical, Legal and Political Dilemmas (CUP 2003) 19.
} 
under its jurisdiction. ${ }^{160}$ However, when a state becomes unwilling to protect the rights of those under its jurisdiction, the international community should be willing to rescue the members of such a state. ${ }^{161}$

This reasoning was first developed by Grotius, a seventeenth century jurist who propounded the notion of a societas humana - the universal community of humankind. ${ }^{162}$ This universality implies a moral duty to help others outside a state's immediate jurisdiction. ${ }^{163}$ He stated that when a prince inflicts tyranny on his subjects, other states are justified to intervene against such a state. ${ }^{164}$ The community of states cannot sit back and allow the rights of several thousands and perhaps millions of people be trampled upon by authoritarian regimes. As a former Secretary-General of the UN put it, 'it would be neither sound morality, nor wise policy... ${ }^{165}$ When the law permits the perpetuation of conduct that is unfair or unjust, actions must be taken and such actions need not wait for a Security Council resolution or "pictures of unfolding atrocities that shock the conscience of the world. ${ }^{166}$ This moral duty is the most basic ground within this common morality for interference in the internal affairs of one nation by outsiders including international bodies. ${ }^{167}$ This normative ground, continues Grotius, exists and will justify the unlawful use of force in extreme situations. $^{168}$

The need for a common front in the protection of human rights was stressed by the ICJ when stating that what is of paramount importance in such situations is the acceptance of common obligations in order to achieve a high objective for all humanity. ${ }^{169}$ During these situations, legal concepts often serve as instruments in defence of the oppressor and not the people of the states involved. The welfare and the security of rights for individuals must therefore be placed above the legal concepts of sovereignty and non-intervention.

The justification for the ECOWAS intervention in Gambia lies in the fact that the right to self-determination was protected by the intervention. Furthermore, there had been

\footnotetext{
${ }^{160}$ Secretary-General, 'Secretary-General defends, clarifies 'Responsibility to Protect' at Berlin event on 'Responsible Sovereignty: International Cooperation for a Changed World' SG/SM/11701 (15 July 2008) $<$ www.un.org/News/Press/docs/2008/sgsm11701.doc.htm> accessed 10 December 2016.

${ }^{161}$ International Commission on Intervention and State Sovereignty (n 143).

${ }^{162}$ Hugo Grotius, De Jure Belli ac Pacis, Book II (OUP 1925) ch 25, quoted in Holzgrefe (n 159) 26.

${ }^{163}$ Joseph Boyle, 'Natural Law and International Ethics' in Terry Nardin and David R Mapel (eds), Traditions of International Ethics (CUP 1992) 123.

${ }^{164}$ Grotius (n 162).

${ }^{165}$ International Commission on Intervention and State Sovereignty (n 143).

166 ibid.

${ }^{167}$ Boyle (n 163) 123.

168 ibid.

${ }^{169}$ Reservations to the Convention on the Prevention and Punishment of the Crime of Genocide [1951] ICJ Rep 23.
} 
widespread allegations against the Jammeh-led government including human rights abuses, ${ }^{170}$ stifling of political opposition, and death in custody. ${ }^{171}$ The situation of things in Gambia had become heightened after the election period showing that a humanitarian catastrophe was looming. ${ }^{172}$ As proof of the sense of insecurity and instability in Gambia, many had begun to migrate into the territory of neighbouring Senegal. ${ }^{173}$ As at the time of intervention, a humanitarian catastrophe was underway and it took the ECOWAS intervention to forestall the humanitarian crisis that could have ensued. The aversion of this crisis is a more legitimate objective to pursue than insisting on legal concepts that would have created a leeway for continued abuse by the Jammeh-led regime.

In conclusion, the norms of international law providing for non-interference in the internal affairs of a state and prohibiting the use of non-defensive force remain valid and should generally be respected. ${ }^{174}$ However, there are situations in which states or international organizations may feel morally compelled to intervene in a state in order to uphold morality and justice. Gambia was one of such cases. There had been widespread allegations of human rights abuses in the twenty-two year-old regime of Yahya Jammeh and his refusal to step down upon losing the 2016 elections was pointer to this intention to hold on to power indefinitely. The winner of the elections, Adama Barrow was also not willing to bow to the tyranny of Jammeh and the catastrophe that could have emerged in the next months, had ECOWAS not intervened, is better imagined than experienced. The ECOWAS intervention was legitimate as it helped to prevent the democratic and political crisis of Gambia from escalating to a full human rights and international crisis.

\section{H. CONCLUSION}

This article traces the facts of the political crisis that emerged in Gambia in 2016 which climaxed in the deployment of ECOWAS troops and the exile of the erstwhile president,

\footnotetext{
${ }^{170}$ Human Rights Watch, 'State of fear: arbitrary arrests, torture, and killings' HRW (New York, 16 September 2015) <www.hrw.org/report/2015/09/16/state-fear/arbitrary-arrests-torture-and-killings> accessed 3 July 2017; Colin Freeman, 'British tourists warned over 'horrific' human rights abuse in Gambia' The Telegraph (London, 17 September 2015) <www.telegraph.co.uk/news/worldnews/africaandindianocean/gambia/11869938/Britishtourists-warned-over-horrific-human-rights-regime-in-Gambia.html> accessed 3 July 2017.

${ }^{171}$ Human Rights Watch, 'More fear than fair: Gambia's 2016 presidential election' $H R W$ (New York, 2 November 2016) <www.hrw.org/report/2016/11/02/more-fear-fair/gambias-2016-presidential-election> accessed 3 July 2017.

${ }^{172}$ Human Rights Watch, 'Gambia: arrests, media closures as deadline nears' HRW (New York, 5 January 2017 <www.hrw.org/news/2017/01/05/gambia-arrests-media-closures-deadline-nears> accessed 3 July 2017.

${ }^{173}$ Hélène Caux, 'Gambians Seek Refuge in Senegal amid Political Tension' United Nations High Commissioner for Refugee News (Geneva, 13 January 2017) $<$ www.unhcr.org/news/latest/2017/1/5878ede04/gambians-seek-refuge-senegal-amid-political-tension.html> accessed 3 July 2017.

${ }^{174}$ See above discussion at section C.
} 
Yahya Jammeh, in January 2017. The UN Charter is clear on its prohibition of the use of force as an instrument of international relations. The Charter only allows force for the purpose of individual or collective self-defence. Every other use of force must be pursuant to a Security Council authorization in exercise of its Chapter VII powers to maintain international peace and security. The ECOWAS intervention in Gambia was neither in selfdefence nor pursuant to a Security Council resolution. The intervention was already underway before Resolution 2337 was passed by the Council and the resolution was silent on the use of military force against Gambia; instead, it emphasized pacific means for the settlement of the dispute.

While consent is recognized under international law as rendering permissible the use of force on a foreign territory, Barrow's plea for support at his inauguration did not constitute a valid invitation for ECOWAS to use force on the Gambian territory. Furthermore, Barrow had no authority to approve the use of force at the relevant time. The general rule is to recognize the person in effective control as the right authority to grant consent for intervention. Barrow was definitely not in control of Gambia at the time of intervention. Besides, the ECOWAS intervention would have gone ahead irrespective of Barrow's speech as the deployment of troops had already begun before his inauguration.

The deployment of troops would have been permissible if the legality of prodemocratic intervention was an established principle under international law. However, the right of states to use force against each other for the promotion or establishment of governmental legitimacy is not firmly established in international law. The right to democratic governance is not supported by the legality of pro-democratic interventions. It would therefore be impossible to rely on the existence of a right to pro-democratic intervention as the basis for the ECOWAS intervention in Gambia.

The ECOWAS intervention in Gambia is undoubtedly illegal: there is no treaty or customary international law which permits this intervention. However, the restoration of stability in Gambia by ECOWAS is worthy of commendation. The positive impact and timeliness of the intervention cannot be overlooked. ECOWAS helped to prevent what may have developed into a civil war in the small West African state. The international community has largely embraced the intervention and perhaps it is time to ask again if there should an emerging right of democratic intervention. 
All articles published in the UCL Journal of Law and Jurisprudence are licensed under the Creative Commons Attribution License (CC-BY) 4.0 international license agreement and published open access, making them immediately and freely available to read and download. The CC-BY license agreement allows authors to retain copyright while allowing others to copy, distribute, and make some uses of the work. Further information regarding this can be found at https://creativecommons.org/licenses/by/4.0/. 